Médicalisation de la gestion hospitalière aux Hôpitaux de l'Assistance publique de Paris qui dénoncent avec virulence la «vision monofactorielle» des DRG. Ils proposent de mieux tenir compte de la complexité des cas, des circonstances de l'hospitalisation, de l'évolution de la maladie et du degré de certitude des diagnostics.

«Les exigences fondamentales prealables à toute création d'une forme intelligible sont la logique et la cohérence», écrivait le compositeur Arnold Schoenberg. Les DRG n'échappent pas à cette règle: la logique et la cohérence clinique des DRG sont essentielles pour rencontrer l'adhésion du corps médical. Dans ce but, et suite aux nombreuses critiques adressées aux DRG, l'équipe de R. B. Fetter a développé de nouvelles versions (The Evolution of DRGs and Clinical Information Systems). Une prise en considération plus differenciée des diagnostics secondaires et de la sévérité a été introduite, une version pédiatrique des DRG a été développée, des programmes de contrôle de la qualité du codage sont maintenant proposés. Des indicateurs cliniques ont également été mis sur pied pour faciliter les contrôles de qualité dans les hôpitaux.
Les indicateurs de qualité se heurtent souvent à une difficulté majeure: comment mesurer l'efficacité d'un traitement en se limitant au seul séjour hospitalier? Des indicateurs tels que les taux de réadmissions ou de mortalité ajustés par la structure des clientèles hospitalières pourraient être développés, à condition de recueillir quelques informations supplémentaires permettant de faire le lien entre les statistiques de morbidité hospitalière et celles de mortalité (Data requirement for a continuous monitoring of the quality of care using $D R G$ ).

Les recommandations concernant l'utilisation des statistiques hospitalières (dernier article) émanent de l'étude Casemix qui vient de se terminer en Suisse. Bien que ces recommandations s'adressent plus particulièrement à la situation helvétique, une part importante d'entre elles restent pertinentes pour la plupart des pays. Les applications retenues dans ces différents pays n'auront pas toutes les mêmes priorités, mais partout, les DRG auront pour fonction première de faciliter le rapprochement de professionnels de formations et de sensibilités différentes.

Yves Eggli, Lausanne

\title{
Editorial
}

\section{What Future for Diagnosis Related Groups?}

While important progress have been realized in public health and clinical medicine since the Second World War, the management of hospitals has evolved comparatively little during the same period. Decision making processes remained the same, in spite of deep mutations in hospital structures and activities. For about twenty years, researchers tried to develop descriptive methods enabling them to grasp the complex nature of hospital activity. An important and inventive effort to medicalize the description of the hospital Casemix has been lead in the United States by R. B. Fetter's team (University of Yale): the Diagnosis Related Groups (DRGs), originally developed to assess hospital production.

DRGs are now being evaluated and are beginning to be used in most European countries. This issue gives an insight into the recent developments as well as the perspectives for use of DRGs in Western Europe. The progress of different national or regional DRG experiences is described in the first article, which pre- sents possible ways of harmonizing the use of DRGs in Europe ("L'Europe des DRG").

What are the reasons for the success of DRGs? On the one hand, DRGs use available, centralized routine hospital statistics. No additional information is needed. On the other hand, the limited number of groups (less than 500 DRGs are enough to group the whole set of in-patients) make them particularly attractive. These two conditions-available routine information and a limited number of groups-are not sufficient to make DRGs useful. They must also be homogeneous in terms of medical meaningfulness and of costs (similar length of stay and resource consumption).

These homogeneity questions are widely discussed in the Swiss and Belgian studies ("Principaux résultats de l'étude suisse sur les DRG" and "Perspectives d'utilisation des DRG en Belgique"), which show that although DRGs have been developed in the United States, they can be used in both countries. Perspectives for DRG use are different, however. For the Swiss study, the 
priority is placed on management applications (calculation of costs, standardized comparisons of length of stay, planning of hospital beds) before looking at a partially DRG-based financing process. The authors admit that the quality and reliability of medical statistics and costs would be better if the financing process were not the only incentive for collecting this information. It will be interesting to see if hospital managers in this country will adopt DRGs as a management tool without direct financial incentive. On the contrary, the Belgian Ministry of Public health is keen on using DRGs as a criterion for hospital budgeting as soon as possible. In order to master application difficulties, the Belgian team is considering reinforcing the control of coding quality and improving the predictive performance of the DRGs on hospital costs, by collecting further information such as the number of physiological systems involved, the kind of admission and reanimation services.

If the introduction of the prospective payment system by DRGs for American hospitals in 1983 made DRGs famous, they probably did not facilitate introduction of DRGs in European countries. Choosing to consider the hospital stay as a financial unit (rather the hospital day or medico-technical services) will encourage hospitals to limit their costs. However, the American experience showed that prospective financing by DRG is not devoid of perverse effects, which explains the strong hesitations, observed in Europe, regarding this financing system. In order to resolve these antithetic proposals, the article about hospital financing ("Financement des hôpitaux et information sur les clientèles hospitalières"), suggests some interesting rules which might help find an original way to reconcile the interest of the concerned parties.

Hospital production cannot be reduced to 500 DRGs without difficulty: within DRGs, important residual variation remains. Reductio ad absurdum, each group would include one patient only, so that we would have perfect homogeneous groups, but for which economic interpretation would be impossible. The validity of the descriptive process increases with the number of categories (because of increasing homogeneity of the groups), but the handling of numerous groups quickly becomes impracticable, especially because many categories gather too few hospital stays. Are DRGs an oversimplification? That is the opinion expressed in the article "Médicalisation de la gestion hospitalière des hopitaux de l'Assistance publique de Paris", which violently criticizes the "mono-factorial" view of DRGs. It suggests taking into account the complexity of cases, circumstances of the hospitalization, the evolution of the illness and the degree of certainty of the diagnoses. "Logic and consistency are the preliminary and fundamental requirements of any intelligible form of creation", wrote the composer Arnold Schoenberg. DRGs do not escape this rule: the logic and clinical meaningfulness of DRGs are essential if they are to meet with the support of physicians. With this in mind, and after the numerous criticisms against DRG, R. B. Fetter's team made new developments ("The evolution of $D R G$ and clinical information systems"). A closer consideration of complications and comorbidities, as well as a better integration of severity has been introduced. Furthermore, a pediatric version of DRGs has been developed. Quality control programs of the coding process are now available and clinical indicators have been elaborated to make quality controls easier.

Quality indicators are often encountering great difficulties: how can the efficacity of treatment be measured by taking into account the hospital stay only? Indicators such as readmission or mortality adjusted by Casemix rates could be developed, as long as one collects some additional information, which make the linkage between morbidity and mortality statistics possible.

The recommendations related to the use of hospital statistics (last article) proceed from the Casemix study, which has recently been completed in Switzerland. Although these recommendations apply more directly to the Swiss scene, most of them are relevant to other countries. The applications selected by these countries will not necessarily have the same priorities, but everywhere the major role if DRGs will be to bring together professionals from various backgrounds and sensibilities.

Yves Eggli, Lausanne 